\title{
MOVED ON: Intertidal atmosphere
}

\author{
Hannah Hopewell
}

The notion of atmosphere offers a cogent conceptual manifold for something that is sensually manifest, yet ambiguous, cloudy and unstable. ${ }^{1}$ Atmospheres function like apertures of immediacy; they hang in space and time as elusive agents of intimacy, resisting manipulation or capture. In this experiment, I take the question of being moved by atmosphere to a brief photographic encounter with a liminal place, and stillness of time, on the slippery ground between the lowest ebb of the tide and the not-yet fullness of day.

My intention is to 'sample' atmosphere, as a spatially discharged 'meeting space', from the intertidal zone of the Mangere Inlet, Auckland, New Zealand. This shallow, broad tidal catchment, marked by incessant processes of human discharge and abandon, expresses complex convergences of often back-grounded bodies, quasi-objects and anonymous forces. I explore whether the diffused intensities circulating in this unremarkable landscape can disclose atmosphere by drawing my intimate attentiveness to the undeterminable. Can this corporeal encounter, the placement of my body and the lens of my camera, impress a present into photographic composition? Can it incite an immanent alterity and make audible the silent, impersonal 'voices' constituent of localized atmosphere?

Atmosphere overflows into apprehension via affective circuits, ${ }^{2}$ and to re-present or image its formlessness is challenging. Whilst atmosphere expresses a palpable territory, there is no singular object or hierarchy around which to organise my photographic focus. This recognition directed my thinking towards the agency of atmosphere as a mode of suspension or interruption of habits of perceptual encounter (Anderson 2009) and prompted me to search for modes of 'looking' outside seeing. Atmosphere might then play a role in de-stratifying the human gaze and its patterns. Perhaps it could decentre, or at least make anthropocentric vantages a little wobbly. ${ }^{3}$ Since full theoretical elaboration lies outside the scope of this paper, I focus on demonstrating how provisional thinking generated a method to catch a momentary quotidian reality unawares.

In my brief encounter with Mangere Inlet in June 2013, at a dawn low tide, I correlated atmosphere with the shady and ephemeral characteristics of thresholds. Photographic acts, edits, and archival selection were organised by three conditions: the orientation and still motion of my body; the automatic settings of my LeicaV-LUX40; and the limits of the transitioning frames within iPhoto. Maximising light, I initiated the image capture orientated skyward. Moving from a bridge above the inlet, I then lowered the camera into the folds of the tidal fields, mud and mangrove. This traversal orchestrated the sequencing. I used the auto settings of my camera and shot very rapidly to suspend normalised seeing and cognitive decision-making. In the serial organisation of the frames, the most incoherent images were deleted and transition into movement was effected with iPhoto's slowest speed of dissolve. 


\section{References}

Anderson, B. (2009). Affective atmospheres. Emotion, space and society, 2(2), 77-81.

Böhme, G. (1993). Atmosphere as the fundamental concept of a new aesthetics. Thesis Eleven, 36(1), 113-126.

Deleuze, G. (1986). Cinema 1: The movement image (H. Tomlinson, B. Habberjam, Trans.). Minneapolis, MN: University of Minnesota Press.

Deleuze, G. \& Guattari, F. (1994). What is philosophy? (H. Tomlinson, G Burchill, Trans.). London: Verso.

Laruelle, F. (2012). Photo-fiction, a non-standard aesthetics (D. Burke, Trans.). Minneapolis, MN: Univocal Publishing.

\section{Endnotes}

1. "Atmospheres are indeterminate above all as regards their ontological status. We are not sure whether we should attribute them to the objects or environments from which they proceed or to the subjects who experience them. We are also unsure where they are. They seem to fill the space with a certain tone of feeling like a haze." (Böhme 1993: 114)

2. Deleuze and Guattari note that "affects are no longer feelings or affections; they go beyond the strength of those who undergo them" (1994:164).

3. See Deleuze's commentary on perception and Vertov's cine-eye (1986: 80-84). 